\title{
Words in Storybooks as Children's Language Input Environment: Substantives
}

\author{
Min Kyung Han, Si Yeon Seong, Sou Jin Choi \\ Department of Communication Disorders, Ewha Womans University, Seoul, Korea
}

\author{
Correspondence: Min Kyung Han, $\mathrm{PhD}$ \\ Department of Communication Disorders, \\ Ewha Womans University, 52 Ewhayeodae-gil, \\ Seodamun-gu, Seoul 03760, Korea \\ Tel: $+82-2-3277-4012$ \\ Fax: +82-2-3277-2122 \\ E-mail:minhan@ewha.ac.kr
}

Received: October 4, 2015

Revised: November 6, 2015

Accepted: November 10, 2015

This work was supported by the BK21 Plus funded by the Ministry of Education of Korea.

\begin{abstract}
Objectives: The purpose of this study was to explore the characteristics of the types and token of substantives in storybooks and to provide suggestions on the use of wordlists based on storybooks. Methods: Twenty-six books in each of three age groups (0-2, 3-4, and 5-7) were selected out of a total of 78 storybooks. Among 14,728 utterances in the selected storybooks, morphological analysis was conducted on 7,184 of the utterances to calculate the types and tokens of substantives including word classes such as common nouns (Common), proper nouns (Proper), dependent nouns (Dependent), pronouns (Pro), and numeral nouns (Numeral). An ANOVA was used to determine the differences in the types and tokens of each word class across age groups. Results: Substantives represented $38.2 \%$ and $26.8 \%$ of the types and tokens, respectively, with the storybooks for 3- to 4-year olds showing the highest the ratios of types and tokens. From greatest to smallest the order of types was Common $>$ Proper $>$ Dependent $>$ Pro $>$ Numeral and the frequency of tokens was Common $>$ Pro $>$ Dependent $=$ Proper $>$ Numeral. The types and tokens of all substantive word classes except for Numeral increased significantly with age. Conclusion: Storybooks, one of children's language input environments, provide a variety of and repeated exposure to substantives, increasing as the age of the storybooks increases, which may influence word acquisition and development in children.
\end{abstract}

Keywords: Substantives, Storybooks, Morphological analysis, Type, Token
일반적으로 아이가 태어나고 모국어를 습득하여 타인과 언어로 의사소통하게 되기까지 비교적 짧은 시간이 걸린다. 보통 아동들 은 1 세 반부터 6 세까지 매일 평균 5 개의 새로운 어휘를 습득하게 되 며(Carey, 1978), 첫 낱말을 1세 경에 산출하고 생후 20-24개월까지 는 어휘 습득에 가속도가 붙어 적어도 6세까지 어휘가 성장한다(as cited in Huttenlocher, Haight, Bryk, Seltzer, \& Lyons, 1991). 이러 한 결과로 6 세가 되면 대략 10,000 개의 어휘를 포함하는 심상어휘 목록(lexicon)을 가지게 된다(Anglin, Miller, \& Wakefield, 1993). 한국 영아들의 어휘발달을 살펴본 Chang-Song (2004a, 2004b)의 연구에 의하면 한국 영아들은 생후 10 개월경에 첫 낱말을 말하기 시작하여 생후 17 개월에 평균 50 개의 어휘를 말하고, 생후 20-21개 월 사이에 100 개의 어휘를 습득하며 생후 36 개월경에는 평균 499 개의 표현어휘를 가진다고 한다. 3-5세의 일반 아동들의 자발화를 수집하여 분석한 Park과 Rhee (2011)의 연구를 살펴보면 3세에서
4 세 사이의 새로운 어휘의 수보다 4 세에서 5 세 사이의 새로운 어휘 의 수가 4 배 이상 많은 것으로 나타났다. 이처럼 취학 전 아동들의 어휘 습득의 속도는 매우 빠르며 연령이 증가할수록 어휘의 수도 증가하게 된다.

이와 관련하여 아동들이 어떻게 어휘를 습득하게 되는지, 어떤 과정을 거치는지, 어휘를 습득하는 데 어떤 요인이 중요하게 영향 을 미치는지를 설명하는 많은 이론들이 있다. 그 중 사회적 화용이 론(social-pragmatics theory)은 의사소통과 언어의 사회적 특성에 중점을 두는데 아동들은 의사소통 상대방과 공유된 참조 체제 (referential framework) 안에서 상호작용함으로써 어휘를 배우게 된다(Akhtar \& Tomasello, 2000)고 설명하고 있다. Akhtar와 Tomasello (2000)에 의하면, 아동들의 초기 언어의 대부분은 일상적 이고 반복적인 사회적 상호작용의 문맥 안에서 학습되는 경향을 보인다고 한다. 그러므로 사회적 화용이론 측면에서는 어휘 발달을 
촉진시키는 언어입력(input) 환경이 중요한 의미를 갖는다. 어휘습 득은 아동의 내재적인 능력과 언어의 노출 요인이 혼합되어 반영되 는데, 언어노출이 어휘 습득에 있어서 결정적인 역할을 하며(Huttenlocher et al., 1991), 언어노출에 의한 언어입력이 초기 어휘 발달 에 개인차를 유발할 수 있는 중요한 환경적 요인 중 하나로 알려져 있다(Rowe, 2012).

아동이 어휘에 노출되는 환경 중 특히 책읽기 활동은 매우 맥락 적인 상황 안에서 새로운 어휘의 우연적인 노출을 빈번하게 제공한 다(Justice, 2002). 아동은 동화책을 보면서 실제 사용하는 언어보 다 더 많은 언어를 접하게 되고, 문맥 속에서 새로운 단어를 접하면 서 어휘를 확장시킨다(McLane \& McNamee, 1990; Ninio, 1983). 만 2세 유아들과 그들의 부모를 대상으로 가정에서의 책읽기 상호 작용이 어휘력과 어떤 관계가 있는지 살펴본 Lim과 Kim (2013)의 연구에서 부모가 아동과 함께하는 읽기 활동량이 많을수록 아동 의 어휘력은 높게 나타났다. 가정에서 이루어지는 책읽기 활동이 아동의 어휘력에 미치는 영향력은 시간이 지날수록 증가하게 되는 데(Sénéchal \& LeFevre, 2001), 이는 책읽기 활동이 어휘력뿐만 아 니라 유치원과 학령기 동안 언어와 읽기 유창성, 읽기 이해와 같은 문해력 발달의 가장 중요한 기초가 되기 때문이다(Mol \& Bus, 2011; Song et al., 2015). 책읽기 활동은 일반아동뿐 아니라 장애아동, 언 어취약 환경에 놓인 아동에게도 중요한 어휘습득환경을 제공하여 수용 및 표현어휘력이 향상되는 결과가 나타났다(Park \& Lee, 2010; Song, 2014; Sun \& Kwon, 2010).

그러나 많은 선행연구들이 책읽기 활동을 통한 어휘습득에는 관심을 가졌지만 책읽기 활동의 매개가 되는 동화책에 등장하는 어휘 자체에 대한 관심은 미비하였다. 동화책 단어는 취학 전 아동 에게 중요한 언어환경 중 하나이며, 동화책읽기를 통하여 입력된 단어는 심상어휘목록에 저장되어 새로운 단어습득, 단어기억, 단 어재인, 단어산출 등 아동의 언어사용에 영향을 미친다. 따라서 동 화책은 유아용 교과서와 같은 역할을 하므로 동화책에 등장하는 단어는 학령전기 한글 교육용 어휘 목록 선정을 위한 기초자료를 제공할 것이다(Yoon \& Yi, 2014). 동화책에 등장하는 어휘에 대한 연구는 Lee와 Kim (2004)에 의하여 수행되었다. 그러나 Lee와 Kim (2004)의 연구는 공신력 있는 기관에 의해 선정된 동화책이 아니라 대구, 경북 지역 유치원 3 곳에서 실제 사용하고 있는 동화책과 10 곳 의 유치원에서 추천한 동화책을 분석 대상으로 하였으며 일부 동 화책에서는 연령 구분을 문장에 사용된 단어의 수에 따라 임의로 3-4세와 5-6세로 대상 연령을 구분하였고 해당 연령별 동화책의 수와 동화책 종류별 구성 비율 등은 나타나 있지 않아 취학 전 아 동의 동화책 어휘 특징으로 일반화하여 해석하기에는 무리가 있다.
이러한 선행연구의 제한점을 토대로, 본 연구는 공신력있는 추천기 관이 제공하는 도서목록을 바탕으로 객관적인 문어(written language)자료를 선정하여, 형태소 분석을 통하여 동화책에 등장하는 단어를 품사별로 분류하여 같은 단어 기능에 속하는 품사들의 유 형 수와 빈도를 연령별로 살펴보았다. 그러나 지면상의 제약으로 본 논문에서는 동화책 단어 중 체언의 분석결과만을 발표하고자 한다. 체언은 한국어의 명사, 대명사, 수사, 동사, 형용사, 관형사, 부사, 감탄사, 조사의 9품사 중 명사, 대명사, 수사를 지칭하며 문장에서 서술어의 동작이나 상태의 대상이 되는 주체로서의 역할을 담당 한다. 명사는 사물의 이름이나 개념을 나타내고, 주어, 목적어, 보어 등으로 사용되며, 일반명사, 고유명사, 의존명사로 구분된다. 대명 사는 사람이나 사물 등 어떤 대상을 간접적으로 지시하는 품사로 인칭대명사와 지시대명사로 세분화된다. 수사는 사물의 수량이나 순서를 나타내는 단어로 양수사와 서수사가 있다(Kang \& Kim, 2004; Kim, 2012). 이러한 명사, 대명사, 수사로 구성되는 체언은 취 학 전 아동들의 어휘습득 및 언어발달에서 다른 품사보다 빠른 발 달 양상을 보이며, 높은 사용률을 보인다(Cho \& Jeon, 2004). 체언 품사중 아동들의 초기 습득 어휘는 명사가 주를 이루는 것으로 알 려져 있는데 이는 명사가 의미하는 바가 구체적이며, 비교적 지각하 기 쉽고(as cited in Chang-Song, 2004a), 유아들과 언어적인 상호 작용을 할 때 의사소통 상대방은 이름 붙이기를 주로 사용 (as cited in Chang-Song, Lim, \& Kwak, 2004)하기 때문인 것으로 설명된다.

본 연구는 취학 전 아동들의 동화책을 대상으로 동화책에서 사 용된 단어의 형태를 분석하여 아동의 언어입력환경으로서의 체언 의 형태적 특징을 연령별로 살펴보고자 한다. 본 연구 결과를 통해 만들어진 동화책 어휘목록은 (1) 교육학, 국어학 등 인접학문의 취 학 전 아동의 한글 교육용 어휘 목록 선정을 위한 기초자료로 사용 될 수 있고, (2) 심리학, 언어학 등 인접학문 및 언어병리학 연구에서 단어특성을 통제하기 위한 어휘자료로 사용될 수 있으며, (3) 언어 병리학 임상 현장에서 중재 목표 단어를 선정하거나 선별할 때 참 고자료로 활용될 수 있을 것이다.

\section{연구 방법}

\section{자료수집}

연구에 사용할 도서를 선정하기 위해 다음과 같은 선정절차를 밟았다. (1) 많은 도서관에서 추천도서목록을 도서선정도구로 사 용하는 최근의 추세(Cha, Kang, \& Jang, 2008; Kim, 2013)에 따라 추천도서목록을 제시하는 기관들(즉, 어린이도서연구회, 행복한 아침독서-책둥이, 북스타트 코리아, 어린이문화진흥회, 네이버 통 
합검색, 한우리독서문화본부, '국립어린이청소년도서관'에 링크된 국립어린이청소년 도서관, 고래가 숨쉬는 도서관, 어린이 평화책, 책으로 따뜻한 세상)을 찾아보았다. (2) 개별 홈페이지에서 동화책 별 연령 구분이 된 취학 전 아동을 위한 추천도서목록을 제공하는 비영리 단체를 선택하였다. 이런 기준으로 (사)어린이도서연구회, (사)행복한 아침독서-책둥이, 북스타트 코리아(책 읽는 사회문화 재단)에서 제공하는 추천도서목록이 최종 선정되었다.

최종 선정된 세 개의 기관에서 수집된 추천도서는 2005년부터 2015년까지 출간된 1,704 권이었다. 이들 추천도서들은 다시 다음과 같은 기준으로 선별한 후 연령별로 분류하였다. (1) 도서의 장르는 문학, 과학, 인문, 사회, 예술 등을 모두 포함하도록 하였다. (2) 도서 의 장르가 골고루 포함되도록 하기 위해 전집류는 제외시켰다. (3) 연령은 기관에서의 분류를 참고하여 크게 0-2세, 3, 4세, 5-7세를 기 준으로 나누었다. (4) 각 기관의 추천도서가 중복되는 경우 분류 연 령은 어린이도서연구회, 책둥이, 북스타트코리아의 순서를 기준으 로 분류하였다. 도서의 권장연령을 가장 세분화시켜 분류한 어린 이도서연구회를 우선순위로 두었고, 북스타트는 5-7세용 도서만을 추천하고 있었기 때문에 가장 하위순위로 두었다. (5) 추천도서목 록 중 제시된 연령기준(0-2세, 3, 4세, 5-7세)에서 벗어나는 경우에 는 연구목록에서 제외하였다. 이러한 기준으로 2005년부터 2015년 까지 출간된 1,704 권의 추천도서 중 본 연구에서는 각 연령별(0-2세, 3,4 세, 5-7세)로 26권씩을 무작위로 선정(randomization)하였다. 연령별 동화책 종류를 보면, $0-2$ 세에서 창작동화 18 권, 번역동화 8 권, 3,4 세에서 창작동화 10 권, 번역동화 16 권, $5-7$ 세에서 창작동화 11 권, 번역동화 14 권, 전래동화 1 권이었다.

\section{자료분석}

본 연구의 분석 대상이 된 78권의 도서에서 도서 본문의 기준은 부모 및 교사가 아동에게 소리 내어 읽어줄 것으로 예상되는 내용 으로서, 삽화나 말 풍선 속에 포함된 글자는 모두 포함시켰고, 주석 은 제외시켰다. 맞춤법과 띄어쓰기는 도서에 쓰여진 본문 그대로 전사하였으며, 한글 맞춤법 오류를 방지하기 위해 한글문서에 먼 저 입력한 후 형태소 분석기 프로그램과의 호환성을 위해 텍스트 파일로 저장하여 사용하였다. 형태소 분석을 위해 국립국어원에서 개발한 "21세기 세종계획: 지능형 형태소 분석기 2.0 (깜짝새)" 내 에서 텍스트 파일을 열어 1차로 자동 태깅을 하였고, 자동 태깅의 오류를 수정하기 위해 2 차로 수동 태깅하였다.

2 차 수동태깅 시에는 앞뒤 문맥에 따른 형태소의 의미를 고려하 여 분석하되, 우선적으로 "한국어 형태소 및 어휘 사용 빈도의 분 석2 (Kang \& Kim, 2004)"와 국립국어원 온라인 표준국어대사전
(http://stdweb2.korean.go.kr/search/List_dic.jsp)의 품사 분류기준 을 따랐으며, 설명이 충분하지 않은 경우 “표준국어문법론”(Nam \& Ko, 1993)"을 참고하였다. 또한 형태소 분석기 프로그램에서 자 주 오류가 발생하는 일부 형태소의 경우 다음과 같은 기준으로 태 깅하도록 결정하였다. (1) '아주아주, 너무너무, 겨우겨우, 모두모두' 등과 같이 강조된 부사어는 따로 분석한다[아주아주 $\rightarrow$ 아주(일반 부사) + 아주(일반부사)]. (2) 의성어와 의태어는 모두 부사로 분석 하며, 반복되어 나타나 있어도 본문에 띄어쓰기가 되어 있지 않으 면 한꺼번에 분석한다[예, 엉금엉금 $\rightarrow$ 엉금엉금(일반부사)]. (3) 웃 음소리는 의성어로서, 감탄사가 아닌 부사로 취급한다. 이때 감탄사 는 직접 말소리로 나올 수 있는 단어만을 취급하도록 한다. (4) 하나 의 형태소인 의성어나 의태어 사이에 기호가 있는 경우 기호를 제외 하고 분석한다[예, 빙 글 $\rightarrow$ 빙글(일반부사) $+\sim$ (붙임표)]. (5) 합성 어나 파생어의 경우, 아동들이 단어를 통째로 인식하는 것으로 간 주하여 분리하지 않고 하나의 형태소로 취급한다[예, 가을바람 $\rightarrow$ 가을바람(일반명사)]. (6) 일반명사라도 등장인물의 이름으로 불리 는 경우 고유명사로 취급한다. (7) 수사의 형태를 하고 있더라도 명 사를 꾸며주는 수관형사의 경우 관형사로 취급한다[예, 다섯 개 $\rightarrow$ 다섯(관형사) + 개(의존명사)]. (8) 준말과 본딧말은 각각 별개의 단 어로 보고 분석하였다(예, 맘/마음, 애/아이 등). 수동태깅 시 오류 방지를 위해 두 차례의 수동태깅을 실시하였다. 1 차 수동태깅 확인 자들과 2 차 수동태깅 확인자들 사이의 신뢰도 평균은 $93.8 \%$ 였다.

본 연구에서 분석대상이 된 어절은 총 14,728 개로 $0-2$ 세용 도서 는 총 1,299 어절로 1 권당 평균 약 50 어절, 3,4 세용 도서는 총 5,015 어절로 1 권당 평균 약 193 어절, $5-7$ 세용 도서는 총 8,414어절로 1권 당 평균 약 324 어절이었다. 이 중 체언은 7,184 어절이었다. 체언의 품 사별 하위분류는 형태소 분석기에서 설정하는 태그인 '보통 명사, 고유 명사, 의존 명사, 대명사, 수사'를 최종 분석 요소로 하였다.

\section{연구 결과}

Table 1에서 알 수 있듯이, 본 연구의 분석 대상이 된 동화책(0-7 세)에 나타난 단어의 총 유형 수는 4,770 개, 총 사용빈도는 28,850 회였다. 이 중 체언의 유형 수가 1,820 개로 $38.2 \%$ 를 차지하였고, 체 언의 사용빈도는 7,743 회로 전체 단어 사용빈도의 $26.8 \%$ 를 차지하 였다. 연령별로 살펴보면, 0-2세용 도서 전체 체언의 유형 수가 203 개로 이 연령대에서 출현하는 전체 단어 유형 수의 $36.6 \%$, 사용빈 도는 713 회로 이 연령대 전체 사용빈도의 $31.5 \%$ 로 나타났다. 3,4 세 용 도서에서 체언의 유형 수가 733 개로 이 연령대에서 출현하는 전 체 단어 유형 수의 $39.5 \%$, 사용빈도가 2,844회로 이 연령대 전체 사 
Table 1. Types and token ratio of substantives in total vocabularies

\begin{tabular}{lrr}
\hline Age (yr) & \multicolumn{1}{c}{ Type } & \multicolumn{1}{c}{ Token } \\
\hline $0-7$ & $1,820 / 4,770(38.2)$ & $7,743 / 28,850(26.8)$ \\
$0-2$ & $203 / 555(36.6)$ & $713 / 2,264(31.5)$ \\
$3-4$ & $733 / 1,856(39.5)$ & $2,844 / 9,894(28.7)$ \\
$5-7$ & $884 / 2,359(37.5)$ & $4,186 / 16,692(25.1)$ \\
\hline
\end{tabular}

Values are presented as the number of substantives/total (\%).

용빈도의 $28.7 \%$ 로 나타났다. 5-7세용 도서에서는 체언의 유형 수가 884 개로 이 연령에서 출현하는 전체 단어 유형 수의 $37.5 \%$, 사용빈 도가 4,186회로 이 연령 총사용빈도의 $25.1 \%$ 로 나타났다.

동화책에 등장하는 체언의 품사 유형별로 살펴보면(Table 2), 일 반명사가 0-2세에서 $81.3 \%, 3,4$ 세에서는 91.0\%, 5-7세에서는 86.4\% 를 차지하여 모든 연령대의 도서에서 가장 많은 비중을 보였는데, 0-7세 전체 동화책에서 일반명사는 유형 수가 1,596 개(87.7\%)로 다 른 품사들보다 압도적으로 높았다. 일반명사 외 다른 품사들이 체 언에서 차지하는 비중은 그 순서에서 조금씩 차이가 났다. 모든 연 령을 포함하는 0-7세 전체 동화책에서 일반명사의 경우 유형 수가 1,596 개로 전체 체언 유형 수의 $87.7 \%$ 라는 압도적인 비율을 차지하 고, 품사별 유형 수는 일반명사>고유명사>의존명사>대명사> 수사의 순서로 나타났다.

사용빈도에 있어서도 일반명사가 각 연령대에서 가장 많은 빈도 를 차지하였는데 0-2세에서 $73.9 \%, 3,4$ 세에서는 $80.2 \%, 5-7$ 세에서 는 $72.5 \%$ 를 차지하였다. 대명사는 0-2세에서 $17.0 \%, 3,4$ 세에서는 $10.8 \%, 5-7$ 세에서는 $10.7 \%$ 로 모든 연령대 도서에서 두 번째로 자주 사용되었다. 일반명사와 대명사 이외의 품사들의 체언 내 사용빈도 순서는 연령대마다 조금씩 차이가 있었다. 모든 연령을 포함하는 0-7세 전체 동화책에서 일반명사의 사용빈도는 5,843회로 총 체언 사용빈도의 $75.5 \%$ 를 차지하였고, 일반명사와 대명사의 사용빈도 를 합하면 $86.8 \%$ 를 차지하였으며, 사용빈도는 일반명사>대명사 $>$ 고유명사 $=$ 의존명사 $>$ 수사의 순서를 보였다.

\section{체언 유형 수 및 사용빈도의 연령별 차이}

체언 품사별 유형 수와사용빈도의 연령별 차이를 살펴보기 위해 일원분산분석을 실시하였는데 그 결과는 Table 3과 같다.

\section{일반명사}

일반명사의 경우 유형 수 평균(표준편차)은 0-2세 9.81 (6.31)개, 3, 4세 36.46 (20.98)개, 5-7세 57.96 (34.34)개였으며, 연령별 유형 수 는 통계적으로 유의미한 차이를 보였다 $\left(F_{(2,75)}=27.36, p<.05\right)$. Bonferroni 사후검증 결과, 일반명사 유형 수는 모든 연령대 도서에서
Table 2. Type and token ratio of word classes in total substantives

\begin{tabular}{llcc}
\hline Age (yr) & Word class & Type & Token \\
\hline $0-7$ & Common & $1,596(87.7)$ & $5,843(75.5)$ \\
& Proper & $74(4.1)$ & $476(6.1)$ \\
& Dependent & $72(4.0)$ & $474(6.1)$ \\
& Pro & $58(3.2)$ & $876(11.3)$ \\
& Numeral & $20(1.1)$ & $74(1.0)$ \\
& Sum & $1,820(100)$ & $7,743(100)$ \\
$0-2$ & Common & $165(81.3)$ & $527(73.9)$ \\
& Proper & $13(6.4)$ & $28(3.9)$ \\
& Dependent & $6(3.0)$ & $10(1.4)$ \\
& Pro & $9(4.4)$ & $121(17.0)$ \\
& Numeral & $10(4.9)$ & $27(3.8)$ \\
& Sum & $203(100)$ & $713(100)$ \\
& Common & $667(91.0)$ & $2,282(80.2)$ \\
& Proper & $15(2.0)$ & $89(3.1)$ \\
& Dependent & $24(3.3)$ & $155(5.5)$ \\
& Pro & $23(3.1)$ & $307(10.8)$ \\
& Numeral & $4(.5)$ & $11(.4)$ \\
& Sum & $733(100)$ & $2,844(100)$ \\
& Common & $764(86.4)$ & $3,034(72.5)$ \\
$5-7$ & Proper & $46(5.2)$ & $359(8.6)$ \\
& Dependent & $42(4.8)$ & $309(7.4)$ \\
& Pro & $26(2.9)$ & $448(10.7)$ \\
& Numeral & $6(.7)$ & $36(.9)$ \\
& Sum & $884(100)$ & $4,186(100)$ \\
\hline & & &
\end{tabular}

Values are presented as the number (\%).

Common $=$ common nouns; Proper $=$ proper nouns; Dependent $=$ dependent nouns; Pro $=$ pronouns; Numeral $=$ numeral nouns .

상호 유의미한 차이를 보였다. 연령별 일반명사의 사용빈도 평균 (표준편차)은 0-2세 20.27 (14.45)회, 3, 4세 67.62 (45.85)회, 5-7세 124.88 (85.33)회로 나타났고, 연령별 사용빈도가 통계적으로 유의 미한 차이를 보였다 $\left(F_{(2,75)}=22.32, p<.05\right)$. Bonferroni 사후검증 결 과, 일반명사의 사용빈도에서도 모든 연령대 도서에서 상호 유의미 한차이가 나타났다.

\section{고유명사}

고유명사의 경우, 유형 수 평균(표준편차)은 0-2세 0.50 (1.27)개, 3,4 세 .58 (0.81)개, 5-7세 3.23 (4.74)개로 나타났고, 연령별 유형 수 는 통계적으로 유의미한 차이를 보였다 $\left(F_{(2,75)}=7.46, p<.05\right)$. Bonferroni 사후검증 결과, 0-2세와 5-7세, 3-5세와 5-7세에서 유의미한 차이를 보였고, 0-2세와 3, 4세는 유의미한 차이를 보이지 않았다. 연령별 고유명사의 사용빈도 평균(표준편차)은 0-2세 1.08 (3.30) 회, 3, 4세 3.42 (5.86)회, 5-7세 14.62 (19.79)회로 나타났고, 연령별 사용빈도가 유의미한 차이를 보였다 $\left(F_{(2,75)}=9.35, p<.05\right)$. Bonferroni 사후검증 결과, 사용빈도는 0-2세와 5-7세, 3, 4세와 5-7세 사이 에서 유의미한 차이가 나타났고, 0-2세와 3, 4 세 사이는 유의미한 차이를 보이지 않았다. 
Table 3. Descriptive statistics and ANOVA results of types and tokens of substantives

\begin{tabular}{|c|c|c|c|c|c|c|c|c|c|c|c|}
\hline \multirow{2}{*}{ Age (yr) } & \multirow{2}{*}{ Word class } & \multicolumn{5}{|c|}{ Type } & \multicolumn{5}{|c|}{ Token } \\
\hline & & $\mathrm{M}$ & SD & Min & Max & $F$ & $\mathrm{M}$ & SD & Min & Max & $F$ \\
\hline $0-2$ & Common & 9.81 & 6.31 & 1 & 24 & $27.36^{*}$ & 20.27 & 14.45 & 1 & 61 & $22.32^{*}$ \\
\hline $3-4$ & & 36.46 & 20.97 & 9 & 78 & & 67.62 & 45.85 & 20 & 162 & \\
\hline $5-7$ & & 57.96 & 34.34 & 11 & 136 & & 124.88 & 85.33 & 25 & 298 & \\
\hline $0-2$ & Proper & .50 & 1.27 & 0 & 5 & $7.46^{*}$ & 1.08 & 3.30 & 0 & 16 & $9.35^{*}$ \\
\hline $3-4$ & & .58 & .81 & 0 & 3 & & 3.42 & 5.86 & 0 & 20 & \\
\hline $5-7$ & & 2.69 & 3.73 & 0 & 11 & & 14.62 & 19.79 & 0 & 66 & \\
\hline $0-2$ & Dependent & .31 & .68 & 0 & 3 & $23.88^{*}$ & .38 & .80 & 0 & 3 & $27.17^{*}$ \\
\hline $3-4$ & & 2.65 & 2.35 & 0 & 8 & & 5.96 & 5.39 & 0 & 18 & \\
\hline $5-7$ & & 4.15 & 2.51 & 1 & 9 & & 11.38 & 7.56 & 1 & 25 & \\
\hline $0-2$ & Pro & 1.00 & .98 & 0 & 4 & $23.09^{*}$ & 4.65 & 8.32 & 0 & 35 & $7.81^{*}$ \\
\hline $3-4$ & & 4.27 & 2.65 & 1 & 11 & & 11.81 & 10.60 & 1 & 46 & \\
\hline $5-7$ & & 5.58 & 3.29 & 0 & 12 & & 16.35 & 12.86 & 0 & 54 & \\
\hline $0-2$ & Numeral & .81 & 2.47 & 0 & 10 & .47 & 1.04 & 3.16 & 0 & 13 & .69 \\
\hline $3-4$ & & .38 & .90 & 0 & 4 & & .42 & .99 & 0 & 4 & \\
\hline $5-7$ & & .62 & .75 & 0 & 2 & & .96 & 1.37 & 0 & 5 & \\
\hline
\end{tabular}

Common =common nouns; Proper $=$ proper nouns; Dependent $=$ dependent nouns; Pro= pronouns; Numeral = numeral nouns . ${ }^{*} p<.05$.

\section{의존명사}

의존명사의 경우, 유형 수 평균(표준편차)은 0-2세 0.31 (.68)개, 3,4 세 2.65 (2.35)개, 5-7세 4.15 (2.51)개로 나타났고, 연령별 유형 수 는 통계적으로 유의미한 차이를 보였다 $\left(F_{(2,75)}=23.88, p<.05\right)$. 의존 명사에 대한 Bonferroni 사후검증 결과, 모든 연령이 서로 유의미 한 차이가 나타났다. 연령별 의존명사의 사용빈도 평균(표준편차) 은 0-2세 0.38 (.80)회, 3-4세 5.96 (5.39)회, 5-7세 11.38 (7.56)회로 나 타났고, 연령별 사용빈도가 통계적으로 유의미한 차이를 나타냈다 $\left(F_{(2,75)}=27.17, p<.05\right)$. Bonferroni 사후검증 결과, 사용빈도는 유형 수와 마찬가지로 모든 연령에서 서로 유의미한 차이가 나타났다.

\section{대명사}

대명사의 경우, 유형 수 평균(표준편차)은 0-2세 1.00 (0.98)개, 3, 4세 4.27 (2.65)개, 5-7세 5.58 (3.29)개로 나타났고, 연령별 유형 수 는 통계적으로 유의미한 차이를 보였다 $\left(F_{(2,75)}=23.09, p<.05\right)$. 대명 사에 대한 Bonferroni 사후검증 결과, 0-2세와 3, 4세, 0-2세와 5-7 세가 서로 유의미한 차이를 보였고, 0-2세와 5-7세는 서로 유의미한 차이를 보이지 않았다. 연령별 대명사의 사용빈도 평균(표준편차) 은 0-2세 4.65 (8.32)회, 3, 4세 11.81 (10.60)회, 5-7세 16.35 (12.86)회 로 나타났고, 연령별 사용빈도가 유의미한 차이를 보였다 $\left(F_{(2,75)}=\right.$ 7.81, $p$ <.05). Bonferroni 사후검증 결과, 사용빈도는 0-2세와 5-7세 사이에서만 유의미한 차이를 보였다.

\section{수사}

수사의 경우, 유형 수 평균(표준편차)은 0-2세 .81 (2.47)개, 3, 4세 0.38 (.90)개, 5-7세 0.62 (0.75)개로 나타났고, 연령별 유형 수에 유의 미한 차이가 없었다 $\left(F_{(2,75)}=.47, p>.05\right)$. 연령별 수사의 사용빈도 평 균(표준편차)은 0-2세 1.04 (3.16)회, 3, 4세 0.42 (.99)회, 5-7세 .96 (1.37)회로 나타났고, 연령별 사용빈도에서도 유의미한 차이를 보이 지 않았다 $\left(F_{(2,75)}=.69, p>.05\right)$.

\section{논의 및 결론}

본 연구는 취학 전 아동의 단어입력환경 중 중요한 부분을 차지 하는 동화책 어휘를 대상으로 형태적 분석을 실시하여 체언을 구 성하는 다섯 품사인 일반명사, 고유명사, 의존명사, 대명사, 수사를 중심으로 단어의 형태적 특성을 살펴보고 그 결과 제시되는 어휘 목록의 활용방안을 재고하고자 한다. 본 연구결과 만들어진 어휘 목록은 문어자료 말뭉치 개발과제의 일환으로 개발이 계속 진행되 고 있음을 밝힌다(자세한 것은 아래 ‘한계점 및 연구방향’ 참조)

\section{체언의 유형 수와 사용빈도}

본 연구에서 분석된 78 권의 동화책에는 전체 체언 유형 수가 품 사 전체 유형 수의 $38.2 \%$, 사용빈도 비율이 품사 전체 사용빈도의 $26.8 \%$ 였다. 이 수치는 동화책 단어를 분석한 Lee와 Kim (2004)의 연구결과(어휘 수 $51.3 \%$, 사용빈도 비율 $48.30 \%$ )보다 낮게 나타났 다. 또한 본 연구에서는 전체 품사에서 체언의 유형 수가 3,4 세> 
5-7세>0-2세 도서 순으로 많았고, 사용빈도 비율은 연령이 높아질 수록 낮아졌다. 이는 Lee와 Kim (2004)의 연구결과와는 상이한 것 으로 Lee 와 Kim (2004)의 연구에서는 3, 4세보다는 5, 6세용 도서 에서 체언의 어휘 수와 사용빈도 비율이 증가하였다. 그러나 동화 책 어휘를 분석한 본 연구와 Lee와 Kim (2004)의 연구는 연령구분, 분석자료, 분석요소, 자료의 크기 등에서 차이가 있기 때문에 연구 결과의 차이점을 해석하는 데 어려움이 있다.

체언 내 품사별 유형 수의 비율은 동화책 전체(0-7세)에서 일반 명사 $(87.7 \%)>$ 고유명사 $(4.1 \%)>$ 의존명사 $(4.0 \%)>$ 대명사 $(3.2 \%)>$ 수사 $(1.1 \%)$ 순서이고, 사용빈도 비율은 일반명사 $(75.5 \%)>$ 대명사 $(11.3 \%)>$ 의존명사 $(6.1 \%)=$ 고유명사 $(6.1 \%)>$ 수사 $(1.0 \%)$ 의 순서로 나타났다. 이러한 유형 수와 사용빈도 순서는 자발화를 분석한 Cha, Kim, Kim, Yoon과 Chang (2014)의 선행 연구와 비슷하였다. Cha 등(2014)은 이 순서를 어휘의 체계를 구분하는 집합의 성격(개 방집합과 폐쇄집합)에 기초하여 설명하고 있다. 즉, 일반명사는 어 휘 구성 단어들이 유동적인 개방집합이라는 어휘적 특성에 따라 체언 중 가장 많은 유형 수와 사용빈도 비율을 나타내며, 대명사와 의존명사는 어휘 구성 단어들이 고정된 폐쇄집합에 속하지만 반복 적으로 사용되는 특성 때문에 한정된 유형 수에도 불구하고 사용 빈도 비율은 높게 나타난 것으로 해석된다.

한편, 본 연구보다 더 많은 어절(65,783 vs. 14,728)을 사용하여 자 발화를 분석한 Cha 등(2014)의 연구결과와 비교해 볼 때, 더 적은 어절을 사용하여 동화책 어휘를 분석한 본 연구에서는 모든 연령 대에서 일반명사의 유형 수 비율과 사용빈도 비율이 높았다. 즉, Cha 등(2014)의 연구에서 일반명사의 유형 수가 2세에서 이 연령 전체 유형 수의 $76.7 \%$, 사용빈도가 이 연령 전체 사용빈도의 $53.0 \%$, 3 세에서는 각각 $74.7 \%, 53.5 \%, 4$ 세에서는 각각 $78.4 \%, 56.6 \%, 5$ 세에 서는 각각 $77.7 \%, 52.2 \%$ 로 나타났다. 이에 비해 본 연구에서는 Table 2 에서 볼 수 있듯이, 모든 연령대에서 일반명사의 유형 수 비율 이 전체 유형 수의 $81.3 \%-91.0 \%$, 사용빈도 비율이 전체 사용빈도의 $72.5 \%-80.2 \%$ 로 나타나 아동은 실제 발화하는 것보다 더 다양한 어휘를 동화책을 통하여 반복적으로 노출될 수 있다고 해석할 수 있다. 이는 동화책 어휘가 취학 전 아동의 어휘습득과 발달에 긍정 적인 영향을 미치는 어휘입력환경임을 반증한다고 볼 수 있겠다.

\section{연령별 체언 특징}

본 연구의 연령별 구분은 한국에서 흔히 사용하는 생활연령으로 출생 연월일을 기준으로 계산하는 만 나이와는 약간 차이가 있다. 본 연구에서 쓰인 가장 어린 연령대인 0-2세는 만 나이로 약 0-1;11 세이고, 3, 4세는 만 나이로 약 2;0-3;11세, 가장 높은 연령대인 5-7세
는 만 나이로 약 4;0-6;11세로 생각할 수 있다. 일반명사와 의존명사 는 유형 수와 사용빈도에서 모든 연령간 유의미한 증가가 있었고, 반대로 수사는 유형 수와 사용빈도에서 모든 연령간 유의미한 차 이가 없었다. 한편 고유명사는 0-2세와 3, 4세 사이에서만 유형 수 와 사용빈도에서 유의미한 차이가 없었고, 나머지 연령 사이에서는 유의미한 차이가 있었다. 대명사의 경우, 유형 수에서는 0-2세와 3, 4세, 0-2세와 5-7세 사이에서만 유의미한 차이가 있었고, 사용빈도 에 있어서는 0-2세와 5-7세 사이에서만 유의미한 증가가 있었다.

0-2세에서 3, 4세 사이의 출현 양상을 살펴볼 때, 고유명사를 제 외한 모든 명사, 즉 일반명사, 의존명사, 대명사의 유형 수가 0-2세 와 3,4 세에서 유의미하게 증가하였고, 사용빈도에 있어서도 일반 명사와 의존명사의 경우 0-2세와 3, 4세에서 유의미하게 증가하였 다. 본 연구에서 사용된 동화책 분류 연령 기준 3,4 세는 실제 아동 들의 연령 기준으로는 만 2;0-3;11세로 이는 아동들이 어휘 폭발기 를 거치는 시기이다. 아동들은 발화에서 약 50 개의 단어를 산출할 수 있기까지 다양한 어휘환경에 반복 노출되어 그 단어를 심상어 휘목록에 저장하고 필요할 때 적절한 단어를 산출할 수 있어야 한 다. 동화책을 접하는 아동들은 어휘 폭발기를 거치는 시기에 이전 보다 유의미하게 더 다양한 일반명사, 의존명사, 대명사를 경험하 며, 일반명사와 의존명사에 빈번하게 노출되면서 어휘 양을 증폭시 키고 어휘 폭발을 가속화시킬 것이다.

수사의 경우, 연령별 유형 수와 사용빈도 비율에서 어느 연령대 에서도 유의미한 차이를 보이지 않는데, 이는 동화책에 등장하는 한정적인 유형(예, '하나, 둘, 셋, 넷')을 반복적으로 사용해야 하기 때문에 연령별로 유의미한 차이가 나지 않았다고 볼 수 있다. 고유 명사의 경우, 0-2세와 3, 4세 사이에 유형 수와 사용빈도에서 유의 미한 증가를 보이지 않다가 3, 4세와 5-7세 사이에 유의미한 차이를 보였는데, 0-2세에는 의성어나 의태어 중심의 고유명사가 주를 이 루고 3, 4세에는 사람이나 동물이름이 주를 이루다가 5-7세에는 사 람이나 동물이름이 이전 연령대보다 2.7배로 증가하였다. 이와 같 이 5-7세용 동화책에서 나타난 고유명사의 사용빈도 증가는 유형 수 증가에 따른 것으로 볼 수 있다. 대명사의 경우, 0-2세와 3, 4세, 0-2세와 5-7세 사이에 유형 수에서는 유의미한 증가를 보이나 사용 빈도에서는 0-2세와 5-7세 사이에서만 차이를 보였다. 이는 0-2세 와 3-4세 사이에 대명사의 유형 수가 큰 폭으로 증가하나 사용빈도 에 있어서는 ‘나, 너, 우리’가 65\% 이상의 높은 빈도를 나타내 연령 과 상관없이 이 세 종류의 대명사가 공통적으로 많이 사용된 것을 알 수 있다. 또한 대명사 ‘나, 너, 우리’의 경우, 동화책에서는 모든 연 령대에서 3-4위권 내의 고빈도 단어이지만 Cha 등(2014)의 구어연 구에서는 '나' 만 모든 연령대에서 3 위권 내의 고빈도 단어이고 '우 
리'는 모든 연령대에서 7-10위권 내의 고빈도 단어이며, '너'는 이 연 구에서 가장 높은 연령인 5 세 때에 10 위권에 진입한 고빈도 단어이 다. 따라서 대명사 '나, 너, 우리’의 사용은 체언의 다른 품사보다도 더 구어와의 차이가 두드러진다고 볼수 있다.

\section{연구 및 임상에서의 어휘목록 활용}

유아 한글 교육용 어휘목록 선정을 위한 Yoon과 Yi (2014)의 연 구에서 목표단어를 의미의 친숙성과 형태의 복잡성에 따라 분류하 였다. 이때, 단어의 친숙성은 의미에 대한 친숙성뿐 아니라 사용빈 도에 따른 친숙성도 있다. 즉, 사용빈도가 높을수록 그 친숙도가 높아지는 것이다. 어휘습득연구에서는 고빈도 단어가 저빈도 단어 에 비해 단어형태와 단어의미대상물 사이의 결합을 더 촉진시키고 (Rice, Oetting, Marquis, Bode, \& Pae, 1994) 노출되는 빈도가 높아 더 견고한 단어심상(lexical representation)을 만들 수 있다(Storkel, 2004)고 밝혔다. 따라서 교육용 어휘 목록 선정 시 단어의미뿐 아니 라 사용빈도에 따른 친숙도도 고려하여야 할 요소이다. 선행연구결 과를 바탕으로, 저빈도 단어보다는 고빈도 단어가 아동들의 기억 에 더 잘 저장된 친숙한 단어이므로 고빈도 단어 위주로 어휘 목록 을 선정할 것을 제안한다. 이때, 본 연구처럼 동화책에 등장하는 단 어들을 바탕으로 만들어진 어휘목록은 유형 수와 사용빈도를 고 려한 취학 전 아동의 교육용 어휘목록 선정을 위한 기초자료로 사 용될 수 있을 것이다.

한편 형태의 복잡성과 관련하여, Yoon과 Yi (2014)는 음절의 위 치와 음절 길이에 따라 세부 등급을 나누었다. 음절과 단어의 형태 는 그 자체의 물리적인 특성에 따라 음절과 단어의 복잡성에 영향 을 미칠 수 있지만, 단어학습에 있어서는 특정 목표 음절 혹은 목표 단어가 속한 전체 언어체계에서의 형태적 특성에 따라 기여도가 달 라지게 된다. 음절의 특성을 드러내는 요소로 알려진 phonotactic probability는 특정 단어 속에 들어있는 목표 음절이 한 나라의 언 어체계에서 얼마나 자주 목표 음절 위치에 출현하는가에 대한 확 률(Vitevitch, Luce, Charles-Luce, \& Kemmerer, 1997)로, 일반적으 로 확률이 높은음절이 더 잘 인출되는 것으로 알려져 있다(예, Beckman \& Edwards, 2000; Frisch, Large, \& Pisoni, 2000; Thorn \& Frankish, 2005). 그리고 단어의 특성을 드러내는 요소로 알려진 neighborhood density는 목표단어와 음운적으로 유사한 이웃 단어들의 집합(Luce \& Pisoni, 1998)을 의미하는데, 일반적으로 이웃단어들 이 많을수록 단어습득에 유리하다고 알려져 있다(예, Storkel, 2004). 그러므로 어휘 목록 선정 시 음절과 단어의 특성에 대한 재고가 이 루어져야 하며, 언어와 어휘체계에 대한 기초자료로 동화책 어휘 목록을 사용할 수 있겠다.
동화책 어휘 목록은 위에서 논의한 유아용 어휘목록 개발 시 기 초자료로 이용될 수 있을 뿐 아니라, 심리학, 언어학 등 인접학문 및 언어병리학 연구에서 단어특성을 통제하기 위한 어휘자료로 사용 될 수 있을 것이다. 예를 들면, 연구 자료로 수용언어에서 저빈도 단 어를 선정할 때 혹은 단일언어사용자와 이중언어사용자의 수용어 휘 차이 연구 등을 수행하기 위해 표준화된 어휘검사도구 외에 수 용어휘목록이 필요할 경우, 동화책 어휘목록을 바탕으로 목표단 어를 선정할 수 있을 것이다.

한편 체언의 품사별 동화책 어휘목록들은 다양한 맥락 속에서 일관적이고 반복적으로 아동들에게 노출되는 언어입력 자극으로 이해할 수 있다. 각 체언 품사별 단어목록들은 연령이 증가할수록 더 많은 유형과 높은 사용빈도 비율을 보이는 단어들의 집합으로 더 강력한 심상어휘목록을 만들 가능성이 높은 단어들의 목록이 라고 할 수 있다. 따라서 언어발달 촉진을 위한 중재 및 교육 프로그 램 수행 시 목표 단어로 고려해 볼 만 하다. 또한 아동이 다양한 사 회적 맥락과 일상적이고 우연적인 상황에서 단어를 습득하고 발달 시킨다는 이론과 선행연구결과를 바탕으로, 언어치료 중재 및 교 육 프로그램 수행 시 아동의 연령과 목표단어의 유형 및 빈도를 고 려하여 목표단어가 나타나는 동화책의 다양한 상황과 맥락을 이 용할 수 있겠다. 예를 들면, 사회적 상호작용에 어려움을 보이는 아 동들에게 동화책을 통하여 단어가 사용되는 사회적 상호작용과 맥락을 간접적으로 경험하게 하는 데 유용할 것이다.

\section{한계점 및 연구방향}

본 연구의 분석대상은 총 14,728 어절로써 이 텍스트 분량이 아 동이 사용하는 어휘의 형태적 경향성을 발견할 만큼 충분한 양인 지 고려해 봐야 한다. 즉, 문어자료를 활용한 어휘목록이 말뭉치 역 할을 하려면 얼마만한 분량의 텍스트가 필요한지 고려해 봐야 한 다. Choi와 Park (2012)은 텍스트가 말뭉치로서의 역할을 하려면 약 50,000 어절이 필요하다고 보았다. 이에 비추어 본 연구 결과로 나온 어휘목록은 아직 말뭉치로 불려지기 어렵다고 할 수 있다. 그 리고 말뭉치로 불려지기 위해서는 텍스트의 양뿐만 아니라 집단의 특징을 대표하는 대표성과 단편적인 정보를 피하고 다양한 자료를 사용하는 균형성을 확보하여야 한다(Choi \& Park, 2012). 자료의 균형성 측면에서, 본 연구에서 사용된 동화책 종류는 창작동화가 39 권, 번역동화가 38 권인데 비해 전래동화가 단 1 권만 포함되어 있 어 전래동화책에 등장하는 특정 단어들이 분석대상에서 제외되었 을 가능성이 있다. 그러나 전래동화에는 취학 전 아동에게는 난이 도가 높은 단어들이 많이 포함되어 있다고 밝힌 선행연구(Lee \& $\mathrm{Kim}, 2004)$ 가 있으므로 전래동화 선정 시 자료의 균형성뿐 아니라 
난이도에도 주의하여야 하겠다. 이와 같은 본 논문의 한계점들은 앞으로의 연구방향으로 연결되어 충분한 문어자료 텍스트 양과 텍 스트의 대표성 및 균형성을 갖춘 어휘목록 말뭉치가 개발되어 본 연구에서 제안한 활용방안들이 이용되기를 기대한다.

\section{REFERENCES}

Akhtar, N., \& Tomasello, M. (2000). The social nature of words and word learning. In R. M. Golinkoff, et al. (Eds.), Becoming a word learner: a debate on lexical acquisition (pp. 115-135). Oxford: Oxford University Press.

Anglin, J. M., Miller, G. A., \& Wakefield, P. C. (1993). Vocabulary development: a morphological analysis. Chicago, IL: Society for Research in Child Development.

Beckman, M. E., \& Edwards, J. (2000). Lexical frequency effects on young children’s imitative productions. In M. B. Broe \& J. B. Pierrehumbert (Eds.), Papers in laboratory phonology V: acquisition and the lexicon (pp. 208-218). Cambridge: Cambridge University Press.

Carey, S. (1978). The child as a word learner. In M. Halle, et al. (Eds.), Linguistic theory and psychological reality (pp. 264-293). Cambridge, MA: MIT Press.

Cha, J. E., Kim, J. M., Kim, S. J., Yoon, M. S., \& Chang, M. S. (2014). Substantives in the vocabulary of typically developing young children. Communication Sciences \& Disorders, 19, 430-446.

Cha, M. K., Kang, E. S., \& Jang, J. S. (2008). The development research on foundation of children library books. Seoul: The National Library for Children \& Young Adults.

Chang-Song, Y. K. (2004a). Early lexical development of Korean infants: 8-17 months. Korean Journal Psychology, 23, 77-99.

Chang-Song, Y. K. (2004b). Early lexical development of Korean infants: 1836 months. Korean Journal of Developmental Psychology, 17, 91-105.

Chang-Song, Y. K., Lim, H. J., \& Kwak, K. (2004). The effects of lexical category of maternal linguistic inputs on early lexical development of Korean infants. Korean Journal of Psychology, 23, 105-120.

Cho, S. M., \& Jeon, E. J. (2004). A study on the male and female infants' vocabulary development. Journal of Korean Language and Culture, 25, 157181.

Choi, S. J., \& Park, B. (2012). Korean language informatics. In J. Y. Shin, et al. (Eds.) Introduction to Korean grammar. Seoul: Jisikkwakyoyang.

Frisch, S. A., Large, N. R., \& Pisoni, D. B. (2000). Perception of wordlikeness: effects of segment probability and length on the processing of nonwords.
Journal of Memory and Language, 42, 481-496.

Huttenlocher, J., Haight, W., Bryk, A., Seltzer, M., \& Lyons, T. (1991). Early vocabulary growth: relation to language input and gender. Developmental Psychology, 27, 236-248.

Justice, L. M. (2002). Word exposure conditions and preschoolers' novel word learning during shared storybook reading. Reading Psychology, 23, 87-106.

Kang, B. M., \& Kim, H. K. (2004). Frequency analysis of Korean morpheme and word usage. Seoul: Korea University, Research Institute of Korea Studies.

Kim, T. K. (2013). The research on the actual condition of little library books. Seoul: National Library of Korea, Research Institute of Library and Information.

Kim, W. K. (2012). Part of speech. In J. Y. Shin, et al. (Eds.) Introduction to Korean grammar. Seoul: Jisikkwakyoyang.

Lee, H. J., \& Kim, J. P. (2004). An analysis of vocabulary in storybooks for preschool children. Korean Journal of Communication Disorders, 9, 57-77.

Lim, S. K., \& Kim, M. S. (2013). The relationship between parents' book reading behavior and home literacy environment and their effect on a toddler's vocabulary. Korea Journal of Child Studies, 34, 1-19.

Luce, P. A., \& Pisoni, D. B. (1998). Recognizing spoken words: the neighborhood activation model. Ear and Hearing, 19, 1-36.

McLane, J. B., \& McNamee, G. D. (1990). Early literacy. Cambridge, MA: Harvard University Press.

Mol, S. E., \& Bus, A. G. (2011). To read or not to read: a meta-analysis of print exposure from infancy to early adulthood. Psychological Bulletin, 137, 267296.

Nam, K. S., \& Ko, Y. G. (1993). The standard Korean grammar. Seoul: Tap Publishing.

Ninio, A. (1983). Joint book reading as a multiple vocabulary acquisition device. Developmental Psychology, 19, 445-451.

Park, J. H., \& Lee, S. H. (2010). The effects of storybook reading along with expanded experience activities on the voluntary literacy behaviors and receptive vocabularies of kindergartners with hearing loss. Special Education Research, 9, 25-47.

Park, M. H., \& Rhee, J. A. (2011). A study for characteristics of vocabulary in spontaneous language sample aged from 3 to 5. Korean Society of Education for Hearing-Language Impairment, 2, 1-13.

Rice, M. L., Oetting, J. B., Marquis, J., Bode, J., \& Pae, S. (1994). Frequency of input effects on word comprehension of children with specific language impairment. Journal of Speech, Language, and Hearing Research, 37, 106- 
122.

Rowe, M. L. (2012). A longitudinal investigation of the role of quantity and quality of child-directed speech in vocabulary development. Child Development, 83, 1762-1774.

Sénéchal, M., \& LeFevre, J. A. (2001). Storybook reading and parent teaching: links to language and literacy development. New Directions for Child and Adolescent Development, (92), 39-52.

Song, H. S. (2014). Effects of holistic language activity by picture books on receptive and expressive vocabularies for children with intellectual disabilities. Journal of Intellectual Disabilities, 16, 315-336.

Song, S., Su, M., Kang, C., Liu, H., Zhang, Y., McBride-Chang, C., ... \& Shu, H. (2015). Tracing children's vocabulary development from preschool through the school-age years: an 8-year longitudinal study. Developmental Science, $18,119-131$.

Storkel, H. L. (2004). Do children acquire dense neighborhoods? An investi- gation of similarity neighborhoods in lexical acquisition. Applied Psycholinguistics, 25, 201-221.

Sun, A. S., \& Kwon, S. H. (2010). Effects of picture book reading on improvement of language skills of children in multi-culture family. Journal of Special Children Education, 12, 255-272.

Thorn, A. S., \& Frankish, C. R. (2005). Long-term knowledge effects on serial recall of nonwords are not exclusively lexical. Journal of Experimental Psychology: Learning, Memory, and Cognition, 31, 729-735.

Vitevitch, M. S., Luce, P. A., Charles-Luce, J., \& Kemmerer, D. (1997). Phonotactics and syllable stress: implications for the processing of spoken nonsense words. Language and Speech, 40, 47-62.

Yoon, G., \& Yi, Y. (2014). Selecting vocabulary lists for Korean alphabet (Hangul) education for preschoolers. Journal of Language and Literature, 9, 6584. 


\section{국문초록}

\section{동화책 어휘를 통해 살펴 본 아동의 언어입력 환경: 체언을 중심으로}

\section{한민경 · 성시연 · 최서진}

이화여자대학교 언어병리학

배경 및 목적: 본 연구는 동화책에 등장하는 단어들 중 체언의 유형과 빈도를 중심으로 그 형태적 특징을 알아보고 연구와 임상에서 동화책에 기반한 어휘목록의 활용방안을 모색하고자 한다. 방법: 1-2세, 3, 4세, 5-7세 각 연령별 26권씩 총 78권의 동화책을 선정하여 동화책에 등장하는 14,728 어절 중 체언에 해당되는 일반명사, 고유명사, 의존명사, 대명사, 수사 등 총 7,184 어절을 중심으로 각 품사의 유형 수와 사용빈도를 계산하고 일원분산분석을 통하여 연령별 유형 수와 사용빈도 차이를 살펴보았다. 결과: 동화책에 등장하는 단 어 중 체언은 전체 유형 수의 $38.2 \%$, 사용빈도 $26.8 \%$ 를 차지하였고 3,4 세용 도서에서 가장 높은 유형 수 비율과 사용빈도 비율을 보였 다. 품사별로는 유형 수에서는 일반명사>고유명사>의존명사> 대명사>수사의 순서로 많았고, 사용빈도는 일반명사>대명사>고유 명사 $=$ 의존명사 $>$ 수사의 순서로 많이 사용되었다. 수사를 제외한 모든 체언 품사들은 연령이 증가할수록 유형 수와 사용빈도 비율이 유의미하게 증가하였다. 논의 및 결론: 아동의 언어입력환경 중 하나인 동화책은 연령이 높아질수록 다양한 체언을 반복적으로 제공 하여 아동의 어휘습득과 발달에 영향을 미치리라 기대된다.

핵심어: 체언, 동화책, 형태소 분석, 유형 수, 빈도

본 연구는 정부(교육부)의 재원으로 BK21 플러스 사업의 지원을 받아수행된 연구임.

\section{참고문헌}

강범모, 김흥규(2004). 한국어 형태소 및 어휘 사용 빈도의 분석 2.0. 서울: 고려대학교 민족문화연구원.

김원경(2012). 품사론. 신지영 외(편). 십게 읽는 한국어학의 이해. 서울: 지식과 교양.

김태경(2013). 작은 도서관 장서구성실태 현황 조사: 도서관연구소 2013년도 하반기 자체연구. 서울: 국립중앙도서관 도서관연구소.

남기심, 고영근(1993). 표준국어문법론. 서울: 탑출판사.

박미혜, 이전아(2011). 자발화 표본에 나타난 3-5세 아동의 어휘 특성. 한국청각언어장애교육연구, 2, 1-13.

박정현, 이소현(2010). 이야기책 읽기와 병행된 확장 경험 활동이 청각장애 유아의 자발적 문해행동 및 어휘력에 미치는 영향. 특수교육, 9, 25-47.

선애순, 권순황(2010). 그림동화책 읽어주기가 다문화가정 아동의 언어능력 향상에 미치는 효과. 특수아동교육연구, 12, 255-272.

송희선(2014). 그림책을 활용한 총체적 언어중재가 지적장애 아동의 수용어휘와 표현어휘에 미치는 영향. 지적장애연구, 16, 315-336.

윤경선, 이유미(2014). 유아한글 교육용 어휘 목록 선정을 위한 연구. 어문론집, 9, 65-84.

이현진, 김주필(2004). 유아용 동화책의 어휘 분석 연구. 언어청각장애연구, 9, 57-77.

임수경, 김명순(2013). 만 2 세 영아-어머니, 영아-아버지의 그림책 읽기행동 및 가정문해환경과 영아의 어휘력 간의 관계. 아동학회지, 34, 1-19.

장유경(2004a). 한국 영아의 초기 어휘발달: 8개월-17개월. 한국심리학회지: 일반, 23, 77-99.

장유경(2004b). 한국 영아의 초기 어휘발달: 18개월-36개월. 한국심리학회지: 발달, 17, 91-105.

장유경, 임현정, 곽금주(2004). 언어적 입력의 품사가 영아의 초기 어휘발달에 미치는 영향. 한국심리학회지: 일반, 23, 105-120.

조성문, 전은진(2004). 남녀 유아의 어휘 발달 연구. 한국언어문화, 25, 157-181.

차미경, 강은슬, 장지숙(2008). 어린이도서관 기초 장서 개발 연구. 서울: 국립어린이청소년도서관.

차재은, 김정미, 김수진, 윤미선, 장문수(2014). 2-5세 일반 아동의 어휘 발달: 체언. 언어청각장애연구, 19, 430-446.

최석재, 박병선(2012). 국어 정보학. 신지영 외(편). 쉽게 읽는 한국어학의 이해. 서울: 지식과 교양. 